\title{
Pancheshwar Multipurpose Project: Nepal's Portion of Water
}

\section{S.B. Pun}

Abstract: On September 20, 1996 an overwhelming 96.5\% of the members present at the Joint Session of the Nepalese Parliament hurriedly ratified the Mahakali Treaty to fulfill the requirements of Article 126 of the 1990 Constitution of Nepal.The then Prime Minister Sher Bahadur Deuba and Water Resources Minister Pashupati SJB Rana provided CPN-UML General Secretary Madhav Kumar Nepal and CPN-UML Mahakali Study Team Coordinator KP Sharma (Oli) written replies on the "equal sharing" of the Mahakali waters. However, despite the lapse of 15 years, the two critical clauses: i) "...equal entitlement in the use of Mahakali waters without prejudice to their respective consumptive uses...," and ii) "...precludes the claim, in any form, by either Party on the unutilized portion of the shares of the waters..." still remain obfuscated and clouded in mist. Is "equal entitlement" (50 percent each) considered after deducting the respective consumptive uses as interpreted but later withdrawn by Minister Rana? Or is this "equal entitlement" (50 percent each) considered prior to deducting the consumptive uses as interpreted by Secretary General MK Nepal and then applying the clause "without prejudice" to their respective consumptive uses? No attempts appear to have been made by Nepal to elicit the Government of India's interpretations on this vital issue.

The Ganges basin supports a massive over 523 million people; i.e., 450 million in India, 45 million in Bangladesh, and 28 million in Nepal. With India's economy growing consistently at a high 8 to $9 \%$ annually, the quality of life of her people is definitely on the rise. This will invariably mean drastic increases in her per capita consumption of water. With Nepal contributing over $72 \%$ of the dry season flows of the Ganges, India's eyes and ears are on Nepal either in the form of "... without prejudice to their respective consumptive uses..." or "...precludes the claim, in any form, ...the unutilized portion of the waters..." However, Nepalese governments from the Panchayat era perceived water, whether by design or otherwise, as a mere secondary component of hydropower. Despite the full knowledge that water has become a scarce diminishing resource, the Nepalese Governments continue to be mesmerized by hydropower. This is manifested by the government unveiling in a span of two years her grand dreams of 10,000 MW in ten years and 25,000 MW in twenty years. This article attempts to delve into the intricacies of the Mahakali waters as expounded by Prime Minister SB Deuba's government during the extremely hurried ratification the Mahakali Treaty in 1996.

Key words: Pancheshwar Multipurpose Project, Mahakali Treaty of 1996, India, Nepal

\section{Foreword}

Much has been said and written on what Nepal can earn from export of power to India from the 6,480 MW Pancheshwar Multipurpose Project. In the aftermath of Mahakali Treaty ratification in September 1996, Water Resources Minister Pashupati S.J.B. Rana, at a press briefing, claimed an annual revenue stream of Rs 21 billion through electricity export to India. K.P. Sharma (Oli) (incidentally, Coordinator of CPN-UML's Mahakali Treaty Study Team) claimed a far more astronomical figure of Rs 120 billion annually. Fourteen years later, in 2010, Prime Minister M.K. Nepal rolled out yet another figure of Rs 45.88 billion annually. ${ }^{1}$ While our political masters competed over the billions of Rupees, another form of competition in megawatts has recently raised its head in the political arena.

In 2007 (2065 VS), the then government, led by the United-CPN Maoists with its CPN-UML administered Ministry of Water Resources, unveiled the grand 10,000 MW of hydropower in 10 years Master Plan. ${ }^{2}$ Barely a year later, Nepali Congress party politicians, under the CPN-UML led government, resorted to an emergency Caesarian-like operation of the Ministry of Water Resources to deliver two wonder babies - the Ministry of Energy and the Ministry of Irrigation. The Nepali Congress politicians further unveiled a master plan even far more grandiose than its predecessor, the 25,000 MW of hydropower in 20 years! ${ }^{3}$ While billions of Rupees with tens of thousands of megawatts were being rolled out in the "second richest water resources endowed country in the world,"4 sadly not a word was uttered about water itself - that valuable diminishing and scarce resource in the Indo-Gangetic basin.

Whether by design or otherwise, electricity has always been projected as the glamorous component of Pancheshwar, which would raise Nepal's living standard to the level of Bhutan's 'Gross National Happiness' (GNP). Little, or in fact nothing, has been said or written on the unglamorous water component of Pancheshwar Multipurpose Project.5 
This article attempts to delve into the complexities and obfuscation of Nepal's portion of water in that much trumpeted 'sun to rise from the west' Mahakali Treaty.

\section{Mahakali Treaty Ratification Night: September 20, 1996}

In the late evening of September 20, 1996 (Ashwin 4, 2053 VS on the Nepalese calendar), Ram Chandra Poudel, Chairman of the Joint Session of the two Houses of Parliament, the meeting giving the floor first to Madhav Kumar Nepal, leader of main Opposition Party and General Secretary of Communist Party of Nepal, the United Marxist Leninist (CPN-UML). ${ }^{5}$ M.K. Nepal harked back to the Nepal-India treaties of Kosi (AD 1954) and Gandaki (AD 1959) concluded by M.P. Koirala and B.P. Koirala, respectively, that the Nepalese now reflect upon with pain and sorrows. He stated that the Nepalese cannot forget the series of Indian objections that blocked international funds for implementing the Kankai, Babai and Sikta irrigation projects. M.K. Nepal further stated that with the then Prime Minister, G.P. Koirala, condoning India's unilateral construction of Tanakpur Barrage on the Mahakali River through the Memorandum of Understanding (MOU), the previous Nepalese wounds have been reopened. M.K. Nepal also pointed out that it was during the repressive Panchayat era government regime that Indian security forces occupied Darchula's Tinkar and the secret 1965 NepalIndia Security Treaty was signed.

M.K. Nepal then revealed that his party, the CPN-UML, had received the following political commitments from His Majesty's Government of Nepal (HMGN) and India, that: ${ }^{6}$

1) The Mahakali is basically a border river,

2) both countries have equal rights to the Mahakali waters,

3) Nepal will sell India a portion of her electricity generated from Pancheshwar and the price of energy will be determined on the avoided cost principle,

4) decision on DPR (Detailed Project Report) will be made through national consensus of an All Party Committee,

5) members to the Mahakali River Commission will be nominated through national consensus, and

6) the entire western Nepal-India border will be demarcated scientifically within a stipulated period of time and the Indian military post removed from Darchula District.

M.K. Nepal called the Water Resources Minister Pashupati S.J.B. Rana's interpretation of Mahakali Treaty's Article 3 totally faulty. Minister Rana had informed the House that Nepal and India will be entitled half-half waters of the Mahakali river after deducting their "respective existing consumptive uses." M.K. Nepal wanted Minister Rana to take back his interpretation from the very rostrum he had uttered it from and to declare in- stead that Nepal and India are entitled half-half waters of the common Mahakali river. M.K. Nepal demanded that the government of Nepal get this same interpretation from the Government of India. ${ }^{7}$

Water Resources Minister Rana replied that the government wanted to transform the Tanakpur problem into opportunity by tying it with Pancheshwar to achieve a "new break-through" in water resources development by opening a "new door" for the export of electricity. On the Kosi and Gandaki river treaties raised by General Secretary M.K. Nepal, Minister Rana agreed that Nepalese nationalism did cry over those treaties then; but that very nationalism now is all smiles - precious smiles - on the Mahakali Treaty.

Regarding "existing consumptive uses" of the Mahakali Treaty, Article 3, Minister Rana referred to Prime Minister Sher Bahadur Deuba's letter of September 26, 1996 (Bhadra 26, 2053 VS) to CPN-UML General Secretary M.K. Nepal, wherein the Prime Minister had already explained that both the countries have "equal entitlement" to the Mahakali waters. After completion of the Pancheshwar Project, Minister Rana stated that both countries "have equal entitlement to the Mahakali waters without prejudice to their existing consumptive uses" (emphasis added). Minister Rana added that this equal entitlement to all the Mahakali waters was the government's stand, implying that anything presented earlier contrary to this would be inadmissible. Minister Rana then proposed to the House an understanding that was prepared with the consensus of the CPN-UML, wherein the Detailed Project Report (DPR) preparation of Pancheshwar Multipurpose Project will be based on the Prime Minister's letter of September 11, 1996 (Bhadra 26, 2053 VS), to the CPN-UML General Secretary; that is, that the four understandings will be undertaken as 'Rashtriya Sankalpas' (National Strictures) ${ }^{8}$ and that an All Party Parliamentary Monitoring Joint Committee will be constituted to provide an overall guidance to the government.

Chairman R.C. Poudel then called for voting at around 10:30pm of September 20, 1996 (Ashwin 4, 2053 VS). Two hundred and twenty Members of Parliament (MPs) voted for the motion to ratify the Mahakali Treaty, only eight MPs voted against the motion, and 31 MPs abstained. ${ }^{9,10}$ As the members present at the joint session of two Houses were 228 and as an overwhelming 220 members (96.5\% of the members present) voted for the ratification of the Treaty, this easily fulfilled the $66 \%$ requirement stipulated by Article 126 of the 1990 Constitution of the Kingdom of Nepal.

"...equal entitlement in the use of Mahakali waters without prejudice to their respective consumptive uses...," and "...precludes the claim, in any form, by either Party on the unutilized 
portion of the shares of the waters..."

1) Mahakali Treaty and Letters of Exchange

The following are the exact wordings in the Mahakali Treaty and Letters of Exchange on the controversy "in the utilization" of Mahakali waters.

Article 3, Paragraph 1 of the Treaty: “...both the Parties agree that they have equal entitlement in the utilization of the waters of the Mahakali River without prejudice to their respective existing consumptive uses of the waters of the Mahakali River.”

Item 3 (b) of the Letters of Exchange: “...understood that Paragraph 3 of Article 3 of the Treaty precludes the claim, in any form, by either Party on the unutilized portion of the shares of the waters of the Mahakali River of that Party without affecting the provision of the withdrawal of the respective shares of the waters of the Mahakali River...”

\section{2) KP Sharma (Oli)'s questions and PSJB Rana's replies ${ }^{11}$}

K.P. Sharma (Oli), Coordinator of CPN-UML's Mahakali Treaty Study Team, fielded the following the questions on August 19, 1996 and August 25, 1996 to Pashupati S.J.B. Rana, Minister for Water Resources. Minister Rana provided the replies on August 22, 1996 and August 27, 1996 on the controversial issue of "the use of Mahakali waters":

Coordinator Oli: Articles 1, 2 and 4 of the Treaty quantifies the amount of water Nepal gets from the Mahakali river, but this is not done so in the case of India. Why?

Minister Rana: Article-1 of the Mahakali Treaty quantifies the amount of water Nepal gets because this is as per the Sarada Barrage agreement of 1920 AD. The quantity of water, as stipulated by Article-2 of the Treaty for Nepal, had to be mentioned to establish Nepal's right in lieu of the Nepalese land availed to India for the left afflux bund of the Tanakpur Barrage. Article-4 quantifies Nepal's water for use in the Dodhara-Chandani area, which was most appropriate from the Sarada canal itself.

India has officially claimed in writing 326 cumecs as her maximum existing consumptive uses (Sarada canal's maximum capacity). This consumption differs from month to month and the average minimum flow of the Mahakali river is only 136 cumecs. Questions have arisen on the Sarada canal's maximum capacity and only after resolving these issues would it be appropriate to quantify on a monthly or daily basis India's water consumption.

The two countries have agreed only on the 582 cumecs flow at the Pancheshwar dam site. As inflows from the watershed below the Pancheshwar dam still need to be ascertained and agreed upon, India's existing consumptive uses can be finalized and included when a separate Pancheshwar Project agreement is signed. Unless and until the Pancheshwar DPR is prepared and mutually agreed upon by both the countries, it is difficult to quantify India's actual existing consumptive uses from the Mahakali river and hence India's quantity has not been indicated in the Treaty.

Coordinator Oli (supplementary question of August 25, 1996): The answer to Question 6 "...the Pancheshwar DPR is prepared and mutually agreed upon by both the countries, it is difficult to quantify India's actual existing consumptive uses...' has been given. Not applicable in Nepal's case but applicable only in the case of India, what difficulty is there? Could you explain?

Minister Rana (supplementary answer): The $1920 \mathrm{AD}$ agreement for constructing the Sarada Barrage quantified Nepal's water from the Mahakali river. To establish Nepal's right for permitting India to tie her left afflux bund to the Nepalese high ground, additional amount of water was quantified. The Treaty recognizes Nepal's as well as India's existing consumptive uses as prior use right. In order to determine India's prior use quantity, the Mahakali river's monthly flows, the minimum flow, Sarada canal's capacity and the quantity of water used previously need to be studied to quantify it. As both parties need to agree, the aim has been for a separate agreement on Pancheshwar Project only after detailed discussion and agreement with the Indian side.

Coordinator Oli: What is Nepal's existing consumptive use and how much is India's?

Minister Rana: While the 1920 AD agreement provides Nepal on an annual average basis 8 cumecs of water from the Mahakali river, the present Mahakali Treaty with Tanakpur's additional water, prior to construction of the Pancheshwar Project, makes Nepal's annual average existing consumptive uses as 41 cumecs. Due to the reasons given above in Answer 6, both parties have yet to mutually finalize India's existing consumptive uses.

Coordinator Oli: Arrangements be made to release water for Nepal from Tanakpur at $241.5 \mathrm{~m}$ sill level.

Minister Rana: His Majesty's Government has already requested the Indian Government accordingly.

Coordinator Oli: How do you interpret item (b) of Clause 3 of the Treaty's Letters of Exchange “...precludes the claim, in any form, by either party on the unutilized portion of the shares of the waters of the Mahakali River of that party..."?

Minister Rana: A commonly accepted principle when interpreting a treaty, requires that good intention and the 
spirit and objectives of the treaty must be understood in a simple manner. The Treaty's Clause 3(b) of the Letters of Exchange's wordings - “...precludes the claim, in any form, by either party on the unutilized portion of the shares of the waters of the Mahakali river of that party without affecting the provision of the withdrawal of the respective shares of the waters of the Mahakali river by each party..." - must be interpreted by putting together the Treaty's Article-3 line 3 in one place. This must not be interpreted independently. When interpreted in this manner, Nepal has full authority over her portion of the water and how Nepal desires to use it is also protected.

Coordinator Oli: After construction of the Pancheshwar Project, over how much of the increased regulated water will Nepal have the right? And India over how much?

Minister Rana: As stipulated by Mahakali Treaty's Article-3, Nepal and India have half-half entitlement ${ }^{12}$ over the increased regulated water of the Mahakali river after construction of the Pancheshwar Project.

Coordinator Oli: As indicated above, can Nepal utilize her portion of the water as per her requirement from any one point without Indian hassles?

Minister Rana: As per Article-5 Clause-2 of the Mahakali Treaty, Nepal or India can take their portion of water from Tanakpur Barrage without any hassles and also from any other mutually agreed points. It should be remembered that to prevent high handedness of any one party, Article- 9 of the Treaty has provisioned the Mahakali Commission.

Coordinator Oli: Regarding liability and benefit sharing arrangement that the mutually agreed DPR will present, is it necessary or not to re-ratify in the form of a treaty? If necessary, then which clause of the Constitution?

Minister Rana: After mutually finalizing the joint DPR that both parties mutually agree upon together with various other works, a comprehensive agreement of the Pancheshwar Project is necessary that will tie and incorporate the utilization and sharing of water and thereby the subject of benefit and liability. As this agreement in actuality determines the Mahakali river water utilization and its sharing, it is clear that the Pancheshwar Project related treaty should also be ratified according to clause (2) Article-126 of the Constitution.

\section{3) Indian Ambassador Parries Nepalese For- eign Minister's Request (MOWR/HMGN 1996)}

In the immediate aftermath of the hectic 'dohari' ${ }^{13}$ between Coordinator Oli and Minister Rana, Dr P.C. Lohani, Nepal's Foreign Minister, wrote on September 10, 1996 the following letter to K.V. Rajan, India's ambassador to Nepal:
"The Main Opposition Party in the Parliament, the Communist Party of Nepal (Unified Marxist Leninist) has sent us a letter dated September 10, 1996 on Mahakali Treaty raising some issues on which they would like to hear the views of the Government of India. I will appreciate if you could respond to their queries as attached and furnish it to us at the earliest."

Ambassador Rajan provided the following classic reply to Minister Lohani the very same day:

“I thank you for Your Excellency's letter of September 10, 1996, enclosing a list of points received from the CPN (UML)... to convey Government of India's observations on these points. Insofar as matters relating to the Mahakali Treaty are concerned, the Parliament of Nepal is currently dealing with the question of ratification of the Treaty. I feel it will be highly inappropriate for us to comment on any aspect since ratification is purely Nepal's internal affair. Hence, I trust I would be excused if I express my inability to comment on this section of the list enclosed with Your Excellency's letter. I would also not like to comment on any item relating to Nepal's relations with third countries [Bhutan]."

\section{4) CPN-UML General Secretary MK Nepal's letter of September 10, 1996 and Prime Minister SB Deuba's reply of (September 11, 1996) (MOWR/HMGN 1996)}

On September 10, 1966 (Bhadra 25, 2053 VS) General Secretary M.K. Nepal requested Prime Minister S.B. Deuba for a public expression of commitments from the governments of both Nepal and India on the following all-encompassing issues (emphasis added):

- Review of 1950 treaty;

- India to provide Nepal an alternate transit route to Bangladesh;

- conclude a longer duration Nepal-India transit facility treaty;

- India to register no objection to Nepal's irrigation and other water resources related development projects in Terai or elsewhere; ${ }^{14}$

- India to provide Nepal navigation route to the sea;

- Demarcate and manage the entire Nepal-India border within a fixed stipulated time in a scientific manner;

- Regulate the Nepal-India border and the movements across it; and

- India to assist in solving the Bhutanese refugee problem;

Apparently, without obtaining the Government of India's commitments in writing, the in-a-hurry Prime Minister Deuba replied to General Secretary M.K. Nepal the very next day, September 11, 1996. The following is the gist of Prime Minister Deuba's reply (emphasis added): 
- The Mahakali River is a "boundary river on major stretches" (and "basically a border river" means the same).

- The treaty's provision, that a portion of Nepal's share of energy shall be sold to India with the quantum of such energy and its price mutually agreed between the two parties, forces India to buy Nepal's power. This is automatic and clear! Saving in costs of energy as compared with generation from other alternative sources (like thermal plant, gas turbine, etc.) excluding hydropower will be the basis for determining electricity price. This is called the avoided cost principle, on which the government is clear.

- According to the Treaty provision, both parties are entitled to equal water from the Pancheshwar Dam after its construction. Article 6 (5?) Clause (i) of the Treaty has protected Nepal's water requirements from the Mahakali river. ${ }^{15}$ By applying this principle as the precedent, Nepal can use the waters of all her rivers and streams in inner Madhes, Terai and other areas as per her requirements. The His Majesty's Government is clear and committed to apply this principle.

- Additionally, Nepal has full right to use the waters of her rivers and streams and His Majesty's Government is committed to use that right. During the visit of Indian Minister Vidhyacharan Shukla in December 1993, the Water Resources Secretaries of both the countries signed an Action Plan wherein during the Detailed Project Report preparation of multipurpose projects, water requirements of $\mathrm{Ne}-$ pal would be given prime consideration.

- Clause 3 (b) of the Letters of Exchange of the Mahakali Treaty has clearly guarded the right to use one's portion of water or let it flow in the river. Provision has been made where Nepal, by foregoing her right on her portion of water, can allow India to use it. But for this a separate treaty is necessary.

- During the Pancheshwar DPR preparation, the Treaty requires that all project related issues in addition to the ones indicated above will be discussed and His Majesty's Government will raise them with India.

- His Majesty's Government of Nepal and Government of India have already decided to send a Joint Survey Team in the coming winter to the Mahakali river origin region and demarcate the border in a scientific manner based on the Sugauli Treaty of 1816, maps and other documents. No foreign military or police will be permitted within the Nepalese territory so demarcated.

- For the construction of Sarada Barrage, Nepal had availed India 2,898.50 acres of land, but some more lands had been availed and India has also concurred that it is so. During the coming meeting of the Nepal-India Joint Technical Border Committee, this issue will be raised. Nepal is committed to get Nepal's territory.
- Both His Majesty's Government and Government of India have agreed to review the 1950 treaty at an appropriate level. This will be moved ahead.

- India has agreed to provide Nepal a land route to Bangladesh with appropriate transit facility. To implement this, His Majesty's Government has taken necessary steps and there will be continuity.

- His Majesty's Government is actively working on a longer duration Nepal-India transit treaty that will study the use of the existing transit facility and incorporate new possible transit technologies.

- India has agreed in principle to provide Nepal a navigation route for trading purposes and also agreed to conduct a detailed study. His Majesty's Government is keen to implement this.

- The two countries have already signed an agreement wherein a three year program has been chalked to demarcate the Nepal-India border scientifically. To implement this, His Majesty's Government is active and will give it continuity.

- During the visit of Nepalese Foreign Minister to India, the two countries have agreed to regularize the present open Nepal-India border. It has been agreed to constitute a joint taskforce that will recommend the modalities to regularize the NepalIndia cross border movements.

- To solve the Bhutanese refugee problems, His Majesty's Government is active in garnering the support of India and other friendly countries.

General comments on the 'doharis' between Coordinator K.P. Sharma (Oli) and Water Resources Minister Pashupati S.J.B. Rana, Foreign Minister Dr P.C. Lohani and Indian ambassador K.V. Rajan, and CPN-UML General Secretary M.K. Nepal and Prime Minister S.B. Deuba;

\section{1) Between Coordinator Sharma (Oli) and Minister Rana}

The questions and answers 'dohari' between Coordinator Oli and Minister Rana started on August 19, 1996 (Bhadra 3, 2053) and terminated within 8 days on August 27, 1996 AD (Bhadra 11, 2053 VS), indicating urgency. A perusal of that 'dohari' in hindsight gives the impression that Coordinator Oli had already succumbed to Article 3 of $\mathrm{M}$ ahakali Treaty's "without prejudice to their respective existing consumptive uses." Both Minister Rana and Coordinator Oli evinced no concern, in fact none, at the inclusion of that clause in the Treaty. This was a crowning victory for India, having far reaching implications for future Nepal-India water dialogues. India sought recognition of this principle from Nepal since late 1970s blocking World Bank and ADB funds for Kankai, Babai and West Rapti. In fact, India proposed and was rebuffed by Nepal's dying Panchayat regime in March 1990 this "subject to the protection of 
the existing uses on the rivers" clause in the draft Treaty on Mutual Cooperation (Bhasin 1994). While Prime Minister Deuba and his Minister Rana had already succumbed to this damaging clause by initialing the Mahakali Treaty in February 1996, Coordinator Oli never uttered a word about the inclusion of that clause. Coordinator Oli appeared more concerned with limiting further damages by questioning why only Nepal's and not India's water requirements were quantified. Furthermore, Minister Rana admitted that India had already officially claimed ${ }^{16}$ in writing 326 cumecs as her existing consumptive uses (Sarada canal's maximum capacity) when Mahakali River's average minimum flow is only 136 cumecs.

Similarly, it is inexplicable why Coordinator Oli did not prod Minister Rana more intensely about the other damaging clause “...precludes the claim, in any form, by either party on the unutilized portion of the shares of the waters of the Mahakali River..." This is another clause with far reaching implications for future Nepal-India water dialogues. Though Coordinator Oli did touch this issue, he failed miserably to grill Minister Rana why such a clause had to be incorporated in the Mahakali Treaty. Coordinator Oli was satisfied with Minister Rana's meek logic "Nepal has full authority over her portion of water and how Nepal desires to use it is also protected." That India protected herself fully through this clause can be ascertained from the South Africa-Lesotho agreement on the Lesotho Highland Water Project. The agreement entitled Lesotho an annual water royalty from South Africa for using water stored in Lesotho. In 1998 alone South Africa paid Lesotho US\$25.3 million for the use of 0.58 billion cubic meters of water. The Pancheshwar Project has a live storage of over 6.6 billion cubic meters of freshwater. Such amounts of water royalty would have surely helped to build the dire infrastructures necessary for Nepal's most impoverished far west region.

\section{2) Between Foreign Minister Lohani and In- dian Ambassador Rajan}

It should be noted that the CPN-UML wrote to Foreign Minister Dr Lohani on September 10, 1996. That very same day, Dr Lohani "transmitted the list of Points" to Ambassador Rajan who again that very day fended off his request with "highly inappropriate for us to comment on any aspect..." One can only marvel at the efficiency of this communication between three different actors from their locations at Balkhu (the CPN-UML's headquarters), Sital Niwas (Ministry of Foreign Affairs), and Lainchaur (Embassy of India) on a single day. Without fire there is no smoke and evidently there was something of importance behind this "efficiency."

\section{3) Between CPN-UML General Secretary Ne- pal and Prime Minister Deuba}

It is no coincidence that Foreign Minister Dr Lohani's letter to Indian Ambassador Rajan and General Secre- tary Nepal's letter to Prime Minister Deuba were both written on the same day, September 10, 1996. While Ambassador Rajan replied Foreign Minister Dr Lohani the same day, Prime Minister Deuba replied Secretary General Nepal the next day on September 11, 1996. No doubt, Mahakali Treaty had cooked up an air of urgency, gravity and importance. However, General Secretary Nepal opted to burden an already over-burdened Mahakali Treaty with mundane Nepal-India macro-issues - the oft-quest for 1950 treaty review, oft-request for transit route to Bangladesh, regulating cross-border movements, navigation route to the sea, transit treaty duration, Bhutanese refugees, etc. Among the eight demands of General Secretary Nepal, the only demand of relevance was "India to register no objection to Nepal's irrigation and other water resources related development projects in Terai or elsewhere." If the CPN-UML General Secretary had confined himself only to the Mahakali issues which, of course, meant Kalapani occupation, then a far more focused, meaningful and unobfuscated Mahakali Treaty would have evolved.

Prime Minister Deuba deliberately ignored Secretary General Nepal's demand for public expression of commitments from both the Nepalese and Indian governments. The Government of India skillfully sidelined itself with the lame excuse "highly inappropriate" to comment since ratification is "Nepal's internal affair." In reply to Secretary General Nepal's "India to register no objection to Nepal's irrigation and other water resources related development projects in Terai or elsewhere," Prime Minister Deuba replied "By applying this principle as the precedent, Nepal can use the waters of all her rivers and streams in inner Madhes, Terai and other areas as per her requirements." This was Prime Minister Deuba's interpretation. However, the Government of India in 2004 had no qualms in blocking the Saudi and European Union funds for the Sikta Irrigation Project on West Rapti. Prime Minister Deuba has also blown his trumpet on the inclusion of the clause "Water requirements of Nepal would be given prime consideration in the utilization of the waters of the Mahakali River." Nepal's Dodhara-Chandani has been waiting 14 long years for this elusive "prime consideration" since 1996 for an insignificant 10 cumecs of water from India's 326 cumecs Main Sarada Canal.

It is inexplicable why Prime Minister Deuba was spared the ordeal of not interpreting Mahakali Treaty's contentious Article 3 "without prejudice to their respective existing consumptive uses.” Secretary General Nepal, preoccupied with more mundane issues like transit route to Bangladesh, Bhutanese refugees, etc., failed the nation by not grilling Prime Minister Deuba with India's "existing consumptive uses" that she now claims from the Lower Sarada Barrage, $160 \mathrm{~km}$ downstream of Tanakpur. Secretary General Nepal, however, did make the claim in the Parliament that Nepal and India 
are entitled half-half waters of the common Mahakali river. On "precludes the claim, in any form," Prime Minister Deuba is deliberately vague replying: "Clause 3 (b) of the Letters of Exchange of the Mahakali Treaty has clearly guarded the right to use one's portion of water or let it flow in the river. Provision has been made where Nepal, by foregoing her right on her portion of water, can allow India to use it. But for this a separate treaty is necessary." One cannot fathom what right has been "guarded" on Nepal's portion of water when she has already agreed not to claim "in any form." Instead of talking about another separate treaty, the Prime Minister should have expunged this "precludes the claim, in any form" clause from the Letters of Exchange itself. History will not forgive Prime Minister Deuba and Secretary General Nepal.

Regarding the Mahakali river origin and Kalapani occupation, Prime Minister Deuba promised Secretary General Nepal in September 1996: "The two countries have already signed an agreement wherein a three year program has been chalked to demarcate the Nepal-India border scientifically... already decided to send a Joint Survey Team in the coming winter to the Mahakali river origin region and demarcate the border in a scientific manner... No foreign military or police will be permitted within the Nepalese territory so demarcated." The Nepalese in general are still ignorant what has happened to our venerable Prime Minister's promise to send a joint survey team in the winter of 1996 with an agreed "three year program" to demarcate the border. With the winter of 2010 already in, the Nepalese, however, do know that fifteen cold winters have elapsed for the Indian security forces manning Nepal's Kalapani heights!

\section{Conclusion: Those Precious Smiles on Nepalese Faces!}

There was undoubtedly an air of extreme urgency both within the Deuba government and some elements within the CPN-UML party to ram through the Mahakali Treaty in Parliament. Within three days Coordinator Oli's 17 questions were swiftly replied by Minister Rana and another four supplementary questions in two days. Similarly, Prime Minister Deuba answered Secretary General Nepal's letter of September 10, 1996 within 24 hours. Also CPN-UML's letter of September 10, 1996 from its Balkhu headquarter to Foreign Minister Dr. Lohani at Shital Niwas was "transmitted" the same day to Lainchaur-based Indian ambassador KV Rajan who had the courtesy to reply Dr. Lohani that very same day. Such was the speed and efficiency among the three actors. Many vouch this "urgency" was all fueled by New Delhi. Having successfully embedded the two extremely vital clauses "without prejudice to their respective existing consumptive uses" and "precludes the claim, in any form, 17 by either Party on the unutilized portion" in the Mahakali Treaty, the Government of India wanted the 'coup de grâce' delivered at the Nepalese Parliament before disgruntled elements, calling for amendments, gain the upper hand! Just six years ago in 1990, the Panchayat regime, even in its last dying days, had humbled India by refusing to succumb to the "protection of existing consumptive uses" on the common rivers.

The "waters of the Mahakali river" still have many, many unanswered questions. Secretary General Nepal called Minister Rana's interpretation of Mahakali Treaty's Article 3 "half-half waters of the Mahakali river after deducting their respective existing consumptive uses" totally faulty. The Secretary General demanded that Minister Rana take back his interpretation from the very parliamentary rostrum he uttered them and declare instead that Nepal and India are entitled halfhalf waters of the common Mahakali river. MK Nepal further added that HMGN get this same interpretation from the Government of India. Minister Rana did acknowledge in the parliament that equal entitlement to all the Mahakali waters was the government's stand and anything contrary to this would be inadmissible. Since September 1996, the nation awaits what interpretation the Government of India has.

Minister Rana, replying to Coordinator Oli, admitted “...it is difficult to quantify India's actual existing consumptive uses..." If so be the case, why was Minister Rana in such earnest to ratify the Treaty without ascertaining India's actual existing consumptive uses? Similarly, Coordinator Oli, who was unhappy with India's un-quantified existing consumptive uses, cannot be excused for hurriedly ratifying the Treaty. Did Minister Rana and Coordinator Oli fall prey to the usual "grand designs" of South Asian politics? Minister Rana, furthermore, informed Coordinator Oli that "India has officially claimed in writing 326 cumecs as her maximum existing consumptive uses (Sarada canal's maximum capacity)." That was India's claim of September 1996. Would India be content with that old 1996 claim when her consumptive uses have increased substantially over the last 15 years? Is September 1996 the agreed cut-off date?

The treaty boasts "water requirements of Nepal shall be given prime consideration." then why does India refuse to provide Nepal an insignificant 10 cumecs of water for Nepal's Dodhara-Chandani as stipulated in the treaty? besides, why does India insist on Nepal canal sill level from Tanakpur Barrage at 245 meter while she draws her Mahakali waters from the sill level of 241.5 meter? is "coaxing" Nepal to draw her waters 3.5 meter (11.6 feet) above that of India called prime consideration? how come the colonial British agreed to have the same sill levels from the 1920 Sarada Barrage at 220.52 meter? why wasn't this sill level dispute sorted out before ratifying the treaty? this dispute deprived Nepal world bank's loan of us $\$ 40$ million earmarked for Mahakali irrigation project- III in 2003. How come, while our venerable prime minister Deuba claims "by applying 
this principle as the precedent, Nepal can use the waters of all her rivers and streams in inner Madhes, Terai and other areas as per her requirements," India torpedoes the Saudi and European Union fund for Sikta Irrigation Project in 2004? These are some of the questions that need to be addressed.

The Deuba government came to power in September 1995, after the Supreme Court's controversial reinstatement of the Nepalese Parliament. Within a space of four months, the Mahakali Treaty was tooled around, hammered and signed on January 29, 1996 at Kathmandu by the two Foreign Ministers, Dr PC Lohani and Pranab Mukherjee. To trumpet their achievements internationally, the Treaty was again signed at the Prime Ministerial level on February 12, 1996 at New Delhi. ${ }^{18}$ With the two vital clauses "without prejudice to their respective existing consumptive uses" and "precludes the claim, in any form" successfully embedded in the Mahakali Treaty, India wanted at all costs an immediate ratification of the Treaty. This was achieved within seven months when the Joint Session of Nepalese parliament ratified it with an astonishing 96.5\% majority on September 20, 1996.

In stark contrast, though President Dwight D. Eisenhower of the USA and Prime Minister John G. Diefenbaker of Canada signed the Columbia River Treaty on January 17, 1961, the Canadian Parliament refused to ratify the Treaty. For three years the two countries renegotiated it. Only after substantial “...improvements to the Treaty and the sales of the downstream power benefits in the United States..." ${ }^{19}$ were incorporated in the Treaty, did the Canadian Parliament finally ratify the Columbia River Treaty, on January 22, 1964. The Deuba government, no doubt, was in a great hurry. But what has that hurry achieved for Nepal when in February 2011 fifteen years elapses? Nepal's portion of water from Pancheshwar still remains obfuscated and shrouded in mist. Is it, as Minister Rana interpreted, half-half waters after deducting the existing consumptive uses? Or is it, as Secretary General Nepal believed, half-half waters (equal entitlements) prior to deduction then "without prejudice" to existing consumptive uses? Instead of getting totally mesmerized by tens of thousands of Megawatt with billions of revenue, our political masters need to get the Government of India's official interpretation. Until then, those precious smiles promised by Minister Rana must await!

\section{End notes}

1. This is the figure of D.B. Singh, Pancheshwar Project Chief quoted in Kantipur (Kathmandu vernacular daily newspaper) August 13, 2009 (Shrawan 29, 2066 VS). Singh also claimed the following benefits to Nepal: Irrigation Rs 5.69 billion, fisheries Rs 16 billion, and carbon credit Rs 4.42 billion.

2. Fifteen member task force, with Somnath Poudel as
Coordinator and Lilanath Bhattarai as Member-Secretary.

3. Twelve member task force (with five previous task force members), with WECS Secretary Kishore Thapa as Coordinator and Bhojraj Regmi as Member-Secretary.

4. This is a common belief, but is in fact a misnomer: Nepal is unarguably rich in water resources, but it is not the "second richest" in that regard.

5. From the "Verbatim Recordings of the Joint Session of Two Houses of Parliament,' dated September 20, 1996 (Ashwin 4, 2053 VS).

6. All reference to His Majesty's Government (HMGN) are from the point in time of the events described when Nepal was a constitutional monarchy. In May 2008 the monarchy was abolished, and Nepal became a federal republic and is now referred as the Government of Nepal (GON).

7. This is a very important demand of General Secretary M.K. Nepal, but one is not sure if India has the same interpretation.

8. A debate has now emerged on whether or not the Parliament passed that 'Rashtriya Sankalpas' as per its regulation.

9. The eight members of Parliament who voted against it were, with their party affiliations: H.L. ShresthaUML, P.R. Tuladhar-UML, M.C. Adhikari-UML, N.M. Bijukchhe-NMKP, A.K. Basukala-NMKP, B.B. Rokaya-NMKP, N. Subedi-Mashal, and P. Thapa-Mashal.

10. Those abstaining were 26 MPs from the CPN-UML, four nominated Upper House MPs, and one from the RPP. The party-wise strength of the Lower House is CPN-UML:88, NC:83, RPP:20, NWPP:4, NSP:3, and Independents:7, for a total of 205 (Dahal 2004:98). The disgruntled MPs basically wanted some amendments to the Treaty before ratification. This was a fair demand; but, strangely, neither Nepali Congress nor CPN-UML's M.K. Nepal and K.P, Oli group were keen to make those amendments.

11. From a Ministry of Water Resources publication on the Mahakali Treaty (in Nepali) dated November 14, 1996 AD (Kartik 29, 2053 VS).

12. Note Minister Rana's statement that reads: "Nepal and India have half-half entitlement over the increased regulated water", not half-half after deducting the existing consumptive uses! (ref. footnote no.6, above).

13. Like the back-and-forth competition in a popular Nepalese song, a duet normally sung between a male and female singer.

14. This is an extremely important issue. The classic Indian objections - (a) on Kankai: the Asian Development Bank (ADB) was keen to provide soft loans but India put in her queries; (b) on Babai: despite Indian objections the World Bank had already notified India as per BP 7.50 that the Bank intended to proceed with the project, but then the Bank postponed the Babai Project; (c) On Sikta: like in Babai, India scared away the donors (EU and Saudi Fund) through vehement objec- 
tions; and (d) on Bagmati: India withdrew her initial objections to Saudi Fund funding.

15. Prime Minister Deuba's letter states: "sandhi ko dhara chha (6) ko upadhara (1)." This is probably a typographical error as the Treaty's "dhara chha" has no "upadhara (1)." Prime Minister Deuba was undoubtedly referring to "dhara (5) ko upadhara (1)," which states (in translation): "Water requirements of Nepal shall be given prime consideration..."

16. India made additional 'existing use' claims from Lower Sarada Barrage, $160 \mathrm{~km}$ downstream of Sarada Barrage.

17. Reliably knowledgeable sources indicate that this most damaging clause - "precludes the claim, in any form" - was surrendered by Nepal's political masters on the fourth and last day (January 29, 1996) of negotiations. Due to this deadlock Pranab Mukherjee, India's Foreign Minister, was preparing to return to New Delhi empty handed from Kathmandu.
18. In response to Coordinator Oli's question why the Treaty had to be signed twice, Minister Rana replied "To give it more importance."

19. Booklet of British Columbia Hydro and Power Authority, October, 1964

\section{References}

BCHPA, 1964, The Columbia River Treaty: Sale of Downstream Benefits, Victoria BC, Canada: British Columbia Hydro and Power Authority; URL: www. citizensforpublicpower.ca/files/uploads/The_Columbia_River_Treaty.pdf.

Bhasin, A.S., 1994. Nepal's Relations with India and China, Delhi: Siba Exim Pvt. Ltd.

Dahal, Ram Kumar, 2004, 'Election and People's Participation in Nepal,' Nepal Journal of Contemporary Studies (Kathmandu), vol.4, no.1.

Subba, Bhim, 2002, 'Water, Nepal and India', in K.M. Dixit and S. Ramachandran, eds., State of Nepal, Kathmandu: Himal Books.

\section{CALENDAR OF EVENTS}

\section{WATER RESOURCES}

15 - 18 January, 2011, Conservation of Rivers and Lakes: Public Participation and Institutional Development, Location: Roorkee, India. More info: http://ahec.org.in

28-30 Jan, 2011, WATERCON 2011, International Conference on Community Based Water Resources Management, Location: Guhati, Assam, India, Contact name: Dr. Shikhar Sarma, Website: http://www. pfifound.org/watercon/

February 2011, Introductory courses in Hydraulics, Hydrology and Flood Risk, Location: Wallingford, UK, Contact HR Wallingford. More info: events. hrwallingford.co.uk/IRHH10.pdf

15-17 Feb, 2011, Course on Introduction to River Hydrology and Hydraulics, Location: Wallingford, Oxfordshire, UK, More Info: www.hrwallingford. co.uk/

15-17 Feb, 2011, 6th International Conference on Dam Engineering, Location Lisbon, Portugal. More info: Website: http://dam11.lnec.pt ; Contact: Eliane Portela Email: eliane@lnec.pt

17-18 Feb, 2011, Course on Flood Risk Analysis \& Management, Location: Wallingford, Oxfordshire, UK, 1 More Info: www.hrwallingford.co.uk/

17-19 Feb 2011, International Conference on Sustainable Water Resources Management and Climate Change Adaptation, Location: Durgapur, West Bengal, India. More info: http://www.nitdgp.ac.in/nit1o/ ceintconf/home.htm, Contact: climatechangeintlconf@ yahoo.in

7-8 March 2011, International Conference on Water Resources Engineering and Management 2011,
Location: Lahore, Punjab, Pakistan. More info: http:// www.uet.edu.pk/Conferences/icwrem2011/

9-11 March 2011 International Conference, "From Local Watershed Management to Integrated River Basin Management at National and Transboundary Levels" Location: Chaing Mai, Thailand; Convened By Mekong River Commission; Contact: -http://www.mrcmekong. org/MRC_news/intl-conference-watershed-mngt.htm 22 March 2011, International Seminar on "Narmada - The Lifeline", Location/details will be announced later. Contact http://www.cbip.org/

22-25 March 2011, Future Waters for Europe. Location: Budapest, Hungary, More info: Website: http://www.oieau.org/spip.php?article91\&lang=en 28-30 March 2011, HydroVision Russia, Location: Moscow, Russia. More info: Website: http://www. hydrovision-russia.com

11-14 April 2011, International Conference on the Status and Future of the World's Large Rivers. Location: Vienna, Austria. More Info: worldslargerivers@boku. ac.at, Website: http://worldslargerivers.boku.ac.at/ wlr/

26 April - 13 May 2011, Water Transport and Distribution I. Location: UNESCO-IHE Delft, The Netherlands. Contact: n.trifunovic@unesco-ihe.org 01-05 May 2011, 2011 NGWA Ground Water Summit and 2011 Ground Water Protection Council Spring Meeting, Location: Baltimore, MD, USA. More info: E-mail: customerservice@ngwa.org, Website: http:// www.ngwa.org/summit2011/

4-5 May, Blue Planet- Berlin Water Dialogue 2011, Contact: http://www.blueplanet-berlin.com/

23-27 May 2011, Short Course on Water Security for

... Remaining in page 61 